\title{
国際食品照射諮問グループ（ICGFI）の活動
}

ICGFI 前議長兼カナダ農務省食品研究所長

N. W. Tape

\section{Activities of the International Consultative Group on Food Irradiation}

N. W. Tape

\section{要約}

食品照射に関して協議を行ったり情報提供を行うことの必要性が1982年に確認され，国連食糧農業機関 (FAO), 国際原子力機関（IAEA），世界保健機関（WHO）の事務局長が率先して食品照射に関する諮問グルー プを設立した。この諮問グループの第一回の会合は1984年に開催された。

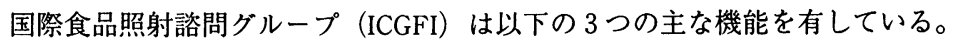

(1) 食品照射の世界的な進展を評価する。

(2) FAO，IAEA，WHO の 3 国際機関及びこれらの国際機関の加盟国に対して助言を与える。

(3) これらの国際機関を通じて, 食品照射に関する合同専門家委員会及び国際食品規格委員会に対して情報提 供を行う。

ICGFI は, 食品照射に係わる安全性の確保, 法律制定, 国民への情報提供, 技術的及び経済的な実用性, トレー ニング, 国際貿易などの問題に対して意見を述べている。ICGFI の活動は, その加盟国の現金拠出かインカイン ド協力によって支援されている。ICGFI の作成するリストやレポート及び ICGFI の開催するワークショップや会 合は, 各国政府, 国連機関及びあらゆる種類の組織に対して, 食品照射の実用化, 技術開発, 表示, 規制, トレー ニングの内容，国民教育などに関する最新の情報を提供している。ICGFIは食品照射施設や許可品目のリストを 作成している。

現在，37ケ国において何らかの食品照射が許可されており，許可されている食品は全部で40種類にも及ぶ。ま た, 約20ケ国は商業規模の照射施設を有している。将来, 食品照射事業者の登録リストが作成される予定である。 食品照射の分野における法律や規制の国際間の調和の支援をするために，ICGFI は各国の法律と規制のリスト を作成している。さらに，食品照射施設の認可や登録に対するモデル的な規制を現在作成中である。ICGFI は， 食品表示に関する規格委員会が照射食品の表示に対する規定を作成する際の支援も行っている。

ICGFI はまた, 食品管理, 検疫処理, 衛生面での品質, 経済性などの話題に関する種々のワークショップを開 催している。ワークショップはすべての地域で開催されており, そのうちの1つは経済性の検討のためのハンド ブックを出版した。

商業的食品照射施設の管理者やオペレーターをトレーニングしたり資格を与えるためのカリキュラムを実施す ることにより, 照射食品の安全性と品質を高める努力をしている。食品の検查官と規制当局者のためのトレーニ 
ングコースも開催している。

ICGFI は，国際食品規格と同様の技術的な指針を，生鮮果物，生鮮野菜，穀物，海産物などの $8 つ の$ 食品のた めに作成した。

食品の衛生面での品質を保証するための放射線照射の利用は，ICGFI の作業部会によって検討され，その報告 费は1987年にWHOによって出版された。

ICGFI の加盟国による一般国民への情報提供の手助けをするために，ICGFI は，食品照射に関するサンプルパ ンフレットを準備している。さらに, ICGFI は照射食品の安全性と健全性に関する印刷物や食品照射に関する短 いビデオを作成している。1988年 4 月にフランスにおいて開催された作業部会は, 食品照射に関して国民に提供 すべき情報を選び出した。

照射食品の国際貿易に係わる問題を検討するために，マーケッテイングと広報活動，植物防疫処理としての照 射，照射食品の貿易の促進について論じるためのいくつかの作業部会が開催された。

ICGFI は, 食品照射に関するあらゆる情報の整理と普及に対する唯一の有効な組織である。過去 4 年間にわたっ て提供された情報量は非常に多い。加盟国はさらに 5 年間の ICGFI の延長に同意した。

\section{はじめに}

国際食品照射諮問グループ（ICGFI）は1984年に設立され，食品照射に係わるあらゆるコンサルティングと情 報提供を行っている。ICGFI の会議の出席や活動資金の提供等の経費が必要であるが，このメンバーになること によって得られる利益はそれを上回るものである。食品照射に対する立場にはかかわらず，ICGFI はすべてのメ ンバーに対して，食品照射技術に対する消費者の受容の現状，規制，管理，実用化，貿易に関する最新の情報を 提供している。

\section{ICGFI の設立}

1982年に，FAO と IAEA とWHO の事務局長が，3つの国連機関の加盟各国に対して，食品照射に関する国 際協力を行うための諮問グループの設立を提案した。この専門家グループは, 政府の指名した専門家によって構 成される組織を想定したものであった。

この提案に応じた45ケ国のうちの44ケ国が提案に賛意を表したので，これら 3 国際機関は1983年に会議を召集 して，ICGFI の設立のための宣言文を作成した。そしてこの会議に参加した19ケ国の代表がこの宣言文を探択し た。ICGFI は当初 5 年間の予定で設立され, 第 1 回の会合は1984年にウイーンで開催され22ケ国が参加した。そ して第 6 回の会合は 2 週間前に終わったばかりである。

\section{ICGFI の錄能}

ICGFI は以下の機能を有している。

a ）世界における食品照射の進展状況を評価する。

b ）加盟国及び 3 国際機関に対して，食品照射の利用に関する助言を与える。

c）要請があれば, 3 機関を通じて, FAD/IAEA/WHO 合同の照射食品の健全性に関する専門家委員会及び国 
際食品規格委員会に対して情報を提供する。

\section{ICGFI への加盟と資金}

現在 ICGFI の加盟国は32ケ国であり，そのうちの 3 分の 2 が途上国である。FAO，WHO，IAEA の代表で構 成されている合同事務局が ICGFI の役員と加盟国に対する支援を行っており，現在，ポーランドのフイッシャー 博士がチェアマンを務めている。

FAO, WHO, IAEA は会議の施設提供や準備を行い, それぞれの加盟国はICGFI の活動を支援するために毎 年資金供与あるいはイン・カインド協力を行っている。年間, 約15万ドルの資金供与が行われており, さらに金 額に直すと 5 万ドルに相当するイン・カインド協力が行われている。

\section{ICGFI への加盟と利点}

ICGFI に加盟すると，食品照射に係わる安全性，法規，規制，基準，経済性，技術的実用性，国民教育, トレー ニングプログラム, 照射食品の貿易に関する最新の情報を得ることができる。さらに, 各国政府は, ICGFI の活 動計画を策定したりその活動に参加することができる。

ICGFI の年次会合には, 国連機関や UNCTAD/GATT の国際貿易センター, 世界銀行のインターナショナルファ イナンスコーポレーション, EC 委員会, 国際工業照射協会 (AIII) 等の国際機関のオブザーバーも参加している。 このような国際機関に加えて, 国際消費者連盟 (IOCU) の代表が, ICGFI の誘いに応じて年次会合にオブザーバー として参加しており，1988年の会合には 2 人の代表が参加した。新しい食品貯蔵技術に関して消費者との対話が 必須である。

\section{食品照射の安全性の確保}

消費者は照射食品の安全性について不安に思っている。ICGFIは食品照射に関する安全性を保証するためにい ろいろな活動を行っている。ICGFI は健全性を含む食品照射に関するあらゆる情報を収集しており，この作業は カールスルーエにある栄養研究所において行っている。さらに, ICGFI は10kGy 以上照射した食品の健全性に関 するデー夕を収集して評価しており，これはFAO, IAEA, WHO 合同の照射食品の健全性に関する専門家委員 会 (JECFI) にとって有益な情報となっている。JECFI は1980年に10kGy 以下の線量を照射した食品は安全で健 全であるという結論を出した。再びJECFI が召集されて10kGy 以上照射した食品の安全性について検討する場 合，多くの実験データを利用することができる。

ICGFI は食品照射工程管理スクールのカリキュラムも作成している。食品照射工程管理スクールの目的は, 商 業照射施設の監督者や作業者の免許を与えるためのトレーニング及び食品の検査官の研修である。このスクール は世界のいろいろなところで開催され，各国政府が適格な人材に商業照射施設を運転させ規制するために役立つ ものである。最初のスクールはカナダ照射センターで1989年 6 月に開かれ， 2 回目のスクールは食品の検查官を 対象としたもので1989年 9 月にオランダで開かれた。

ICGFI は，各国の基準や規制手順を調和して照射食品の貿易を促進するために，8つの食品に対する技術的な ガイドラインを作成しており，これらのガイドラインは食品照射の実用化の際の実施規範となる。アメリカ材料 
検査協会（ASTM）は，現在，実施規範として確立するためにこのガイドラインを見直している。さらに，この ガイドラインを拡充し，技術的なモノグラフを作成することを検討している。モノグラフは個々の食品の照射法 について述べたものであり，個々の国である食品の照射が提案された時にそれを評価する手助けとなるであろう。

\section{規制と基準}

ICGFI は各国における食品照射の法規制の現状を調査しそれを公表している。1987年に許可リストを作成し， それには39ケ国における食品照射の許可状況が載っている。また, ICGFIは食品照射施設の許可のための規制モ デルも作成しており，1990年に公表する予定である。さらにICGFI は照射食品の表示の国際基準の作成を支援 している。国際食品規格委員会食品表示部会は1989年春に食品表示に関する規格の改正を検討し, 食品が照射さ れたことを示す明確な言葉の使用を義務付け，必要ならばロゴの使用をオプションとすることを決めた。国際食 品規格委員会は1989年 7 月にこの改正案をアクセプタンスプロシージャーの次のステップに進めた。この改正案 は1991年の国際食品規格委員会で採択される見込みである。

\section{消零者への情報の提供}

ICGFI は1987年に，加盟国が国民に対して食品照射の安全性に関する情報を提供する際の手助けとなることを 目的とした「照射食品の安全性と健全性」というファクトシートを作成した。また，ICGFI は食品照射に関する ビデオも作成しており，その1つは「食品照射，食品を処理する新しい方法」というタイトルのものである。も う 1 つ1988年のジュネーブの国際政府会議で使用されたスライドのビデオが作成されている。これらはウイーン の ICGFI 事務局で手に入れることができる。いろいろな側面から捕らえた食品照射に関する 5 つのモデルパン フレットが作成されており，これは，政府，業界団体，専門家協会が利用するためのものである。ICGFI は1988 年 4 月にフランスで食品照射に関する消費者教育について議論するための作業会議を開催し，その勧告も入手可 能である。

\section{トレーニングプログラム}

ICGFI は食品の管理，検疫処理，衛生面での品質，経済性，ポストハーベストロスなどのさまざまな話題に関 するワークショップを年間 $2 \sim 3$ 開催している。これらのワークショップは, 作業者や検疫官のための食品照射 工程管理スクールのトレーニングを補うものである。各国政府が家禽肉, 水産物, 香辛料における食中毒菌の除 去法を模索しているので, 照射食品の衛生面での品質に関するワークショップは特に関心が高い。

\section{食品照射の技術的・経済的実用性}

すべての食品に適用できる食品保存法というものはなく, 食品照射は, 缶詰, 冷凍, 乾燥などと同様, 技術的 および経済的な制約がある。ICGFI はフィージビリティスタディ実施のためのハンドブックを作成した。これは 国際食品照射技術施設（IFFIT）が行った経済性に関するワークショップのプロシーディングを基に作成したも のであり,アメリカにより出版された。 


\section{国際貿易}

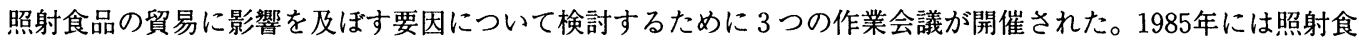
品の貿易促進に関する作業会議が開催され，1986年には夕イで防疫処理としての食品照射に関する作業会議が開 かれた。同じ年にカナダで作業会議が開催され，食品照射のマーケッティングと広報について論議され，「食品 照射の受容のためのガイドライン」が作成された。1989年11月の下旬にフロリダで開催されるアメリカ地域の会 議では，照射食品の貿易に係わる規制の調和について論議されることになっている。

\section{情報の収集}

ICGFI は, 認可された照射施設, 許可品目, 各国の法規制, 試験販売の実施状況, 各国政府や関係団体の政策 · 方針など食品照射に関するいろいろな情報を収集している。

\section{8年の国際会竡}

ICGFIは，1988年12月にジュネーブが開催された食品照射の受容, 管理, 貿易に関する国際会議の計画をFAO, WHO，IAEA，ITC が立案するのを支援した。この会議には57ケ国の政府及び14の国際機関からの参加者を得て， 食品照射に関する文書を一致して採択した。各国政府の同意のもとに照射食品の開発及び実用化に関する8つの 勧告が出された。食品照射に関する見解が各国で異なっていることを考えれば，これだけ多くの政府および国際 機関の意見の一致をみたということは驚くべきことである。会議では以下のことが確認された。

（a）食品照射は，食品，特に固体食品の病原菌污染を低減させて食品由来の病気を減少させる可能性を秘めてい る。

（b）食品照射は，農産物のポストハーベストロスを減少させることができる。さらに，食品照射はある種の農産 物の植物防疫手段として有効であり，農産物の国際間貿易を促進する。

(c)「照射食品に関する国際一般規格」および「食品照射の実施に関する国際模範」に従った，政府当局による 規制・管理の実施が食品照射の導入の前提となる。

（d） 食品照射に関する各国の規制を国際的に認められた基準に基づいて調和することにより，照射食品の国際間 貿易が促進されるであろう。

(e) 消費者の受容が食品照射の成功にとっての重要な因子である。

\section{ICGFI の延長}

ICGFI のメンバー国および関係する国際機関は ICGFI の過去 5 年間の活動をレビューし，大多数のメンバー国 はICGFIを 5 年延長することに同意した。ICGFI の役割と活動は本質的に変わっておらず，ICGFI は1994年 5 月 まで延長されることになった。

\section{結論}

食品照射は年代ごとに段階があり，1950年代と1960年代は研究開発が行われ，1970年代は安全性が検討され， 1980年代には国内及び国際的な基準や規制が作成された。食品照射の実用化の速度を予測することはむずかしい 
が，食品照射の実用化と照射食品の貿易はゆるやかではあるけれども着実に進展するだろうという兆候が見られ る。

1988年12月にジュネーブで開かれた会議が成功した。この会議においては, 57ケ国が食品照射の有用性を認め, 1 ケ国が棄権をし，2 ケ国が態度を保留した。さらに，EC 理事会の食品照射に関する草案が作られておりこ れにより EC 内での特定の食品照射の利用を認めることになるであろう。

食品照射の研究を実施している国，食品照射を認可している国，食品照射を実用化している国が増えている。 約70ケ国で食品照射の研究開発を行っており，10ケ国に食品照射の研究所がある。世界全体で合計50品目の食品 の照射が認められている。37ケ国において食品照射が許可されており，4ケ国で食品照射は完全に禁止されてい る。20ケ国において食品照射が実用化されており，食品照射用の施設の建設計画のある国が12ケ国ある。照射さ れる食品の量は 1 年間で約 50 万トンである。

各国政府が食品照射に関する情報を求めていることは, ICGFIのメンバーが着実に増えていることからもわか る。2 年以内に ICGFI の加盟国は40ケ国になるであろう。

多くの新しい技術の実用化において消費者の理解が重要な役割を果たしている。この問題をどのように取り扱 うかがこれからの課題である。電子レンジでの経験が食品照射でも絽り返すのであろうか。最初多くの消費者は 電子レンジに懸念を有していたが，その利点が明らかになると，電子レンジの売上は急速に伸びた。消費者は食 品照射の利点を認識すれば照射食品を受け入れるようになるであろうか。われわれは, 政府や産業界の科学者及 び技術者として，新しい技術に関して消費者ともっと頻繁に接触しなければならない。

食品照射に関しては，どういう立場にある人であれ，正しい情報に基づいた決断を下すために，情報が必要で ある。ICGFIの主要な目的は食品照射に関する情報を収集して提供することである。食品照射に対して賛成する 人も反対する人も，ICGFI の活動や情報を利用することができる。 